\title{
Caudal duplication
}

INSERM

\section{Source}

INSERM. (1999). Orphanet: an online rare disease and orphan drug data base. Caudal duplication. ORPHA:1756

Caudal duplication (CD) is a rare developmental anomaly in which structures derived from the embryonic cloaca and notochord are duplicated to varying extents. 